\title{
Income, educational attainment, and green infrastruc- ture in Houston, Texas, USA
}

\author{
Macey Denai McCracken ${ }^{1}$, Atsuko Kawakami ${ }^{2 *}$, Anne E. Egelston ${ }^{3}$ \\ 1, 2,3 Tarleton State University, Stephenville, TX
}

\section{Keywords \\ Income level \\ Educational attainment \\ Green infrastructure \\ Stormwater}

Received: 15 December 2018

Accepted: 18 January 2019

Published: 20 February 2019

\begin{abstract}
This study focuses on socioeconomically disadvantaged areas that desperately need green infrastructures because of their low elevation and adjacent location to hurricane-prone coastal areas. By investigating educational attainment, poverty, and ethnicity data taken from the United States Census Bureau and combining it with Google Earth Street View data, green infrastructures are identified and studied in this work. Within Houston, Texas, the socioeconomically disadvantaged have more green infrastructures than higher education and income levels. The results argue that the pattern of green infrastructure development in Houston is not so much due to the residents' interest and concern for the environment. However, it is more likely the result of past flood events. This research indicates that ethnicity may correlate more closely to the location of green infrastructures within the Houston area than previously indicated. The results are discussed with the historical perspective as well as the federal and local government's effort and potential policy implications.
\end{abstract}

\section{INTRODUCTION}

Within the United States, climate change is leading to differences in not only the environment, but in economic and social changes as well. One location within the United States that has recently been affected by vast growth and changing precipitation patterns from climate change is Houston, Texas. In combination with rapid urbanization, large amounts of precipitation, like those endured during Hurricane Harvey in 2017, can quickly lead to largescale urban flooding. Hurricane Harvey produced an average rainfall of 47.4 inches over the county in the five-day period from August 26-29, 2017. Harris County Flood Control District (2018) believes that 154,170 structures flooded in Harris County, including Houston.

In the aftermath of Hurricane Harvey, interest in preventing repeat instances of catastrophic flooding understandably escalates. The State of Texas, in the 2019 legislative session, passed Senate Bill 7 in order to better prepare the Texas Gulf Coast for future storms. This new legislation includes $\$ 1.6$ billion dollars in funding. Some precautions taken to help reduce the risk of such devastating events on residents, city functions, and property, are the implementation of green infrastructures (Kousky, Olmstead, Walls, \& Macauley, 2013; Sonne, 2014).

Current scholarly literature theorizes that areas with higher poverty levels and less education are less likely to have green infrastructures to protect against extreme weather events such as flooding (Cutter, Boruff, \& Shirley, 2003; Muttarak \& Lutz, 2014). Because residents of these areas, which have higher poverty levels, will not have the financial stability to put green infrastructures in place, one can expect to find less of these features. Additionally, if the residents of an area have lower educational attainment levels, it is not probable that they will have been exposed to concepts of alternative stormwater management, such as green infrastructures. Therefore, fewer green infrastructures will be located in areas with higher poverty levels and lower educational attainment levels.

\section{Objectives of the Study}

The purpose of this paper is to confirm this theory by looking at the green infrastructures located in an area that suf-

\footnotetext{
*corresponding author: Atsuko Kawakami

†email: kawakami@tarleton.edu
} 
fers from flooding on a regular basis. We thus ask the question; does socioeconomic status continue to be a leading indicator of green infrastructure implementation in the hurricane prone location of Houston, Texas?

The paper opens by providing background information about green infrastructures. The next section covers the scholarly literature regarding green infrastructure, poverty, and education levels. We next turn to stating our methodology for this research, followed by our results and a comparison to other scholarly work. This paper concludes by outlining future plans for this research area.

\section{Background}

The Houston metropolitan area is located within Harris County, Texas. It consists of both the incorporated city of Houston, other cities, and unincorporated Harris County. Flood control and emergency services is provided by a dizzying array of local government agencies including, but not limited to, the City of Houston, the Harris County Flood Control District, the Harris County Office of Emergency Management, and the Harris County Sherriff's Office. Each of these offices coordinate activities in the preparation, response, and recovery from major flooding events, including hurricanes. Hurricanes and flood events occur regularly in the Houston area, with the most recent major floods taking place in 2015 (Memorial Day flood), 2016 (Tax Day flood), and 2017's Hurricane Harvey.

In addition to city and county services, the independent school district provides public education for K-12. These institutions are governed separately from both the city and the county. Residents of the independent school district elect a board of trustees to oversee the operation of the school system. Independent school district boundaries are drawn by the Texas State Legislature without respect for city boundaries. As a result, major cities commonly have multiple independent school districts.

Houston is approximately 50 miles inland from the Gulf of Mexico as measured to Galveston Island. However, water is a prominent feature within the city with significant annual rainfall and numerous water features. The City of Houston has a humid subtropical climate with 49.77 inches of average rainfall, as calculated from the time-period of 1981-2010 (National Oceanic and Atmospheric Administration, 2019). All told, there are 22 distinct watersheds in the Harris County area, each with its own distinctive flood pattern. One of the most prominent waterways is Buffalo Bayou. It runs through the downtown Houston area and connects to Galveston Bay in a major industrial waterway known as the Port of Houston.
The Houston metropolitan area has grown extensively in the last few decades, complicating efforts to maintain the area's stormwater infrastructure. U.S. Census Bureau Data indicates that Houston's population has changed from 1,594,138 in 1980 (U.S. Census Bureau, 1998) to an estimated 2,267,336 people in 2017 (U.S. Census Bureau, 2017a). Khan (2005) determined that the urban expansion in Houston has led to a significant increase in the amount of concrete and asphalt that has been laid down. Between 1984-1994 these areas increased by 21\%, 1994-2000 had a 39\% growth, while 2000-2003 saw an increase of asphalt and concrete by $114 \%$ (Khan, 2005). Given the continued rapid growth of Houston as shown in the census statistics, it is reasonable to conclude that the increase in the amount of concrete and asphalt that installed has continued to grow in the time-period between 2003 and 2017. This rapid growth has simultaneously increased the amount of impervious surfaces within the numerous flood plains and increased the number of citizens who rely on the stormwater infrastructure for protection during these natural disasters.

Davis and McCuen (2005) believe that the more recently urbanized areas are being built at such increased rates that proper design and development strategies are not always implemented. Increases in these types of impervious structures, such as roads, parking lots, and roofs, prevent infiltration of precipitation and stormwater. These developments lead to increased runoff rates and volumes from these areas (Mays \& Tung, 1992), resulting in the need of expanded stormwater drainage systems.

Traditionally, grey stormwater systems are commonly made up of a large combination of inlets, manholes, sewers, and junctions (Mays \& Tung, 1992). Additional control devices such as weirs, gates, valves, pumping stations, and regulators are often used as ways to divide the large storm sewer system into a series of subsystems. The shaping of such systems is dendritic in nature and can closely be compared to that of a tree. In other words, the outermost pipes begin small and numerous, but as the flow from each of the individual pipes converge, the average size of each pipe becomes larger in diameter with a corresponding decrease in the number of pipes.

The traditional method of urban stormwater management proceeds to move vast amounts of water out of the area quickly using the previously described systems. While this network appears to work well for city life, it results in many negative impacts on the environment including disruption of the hydrologic systems in the following ways: groundwater depletion, downstream flooding, channel ero- 
sion, and stream ecosystem damages (Dhakal \& Chevalier, 2016; Marobhe \& Hembe, 2019).

On the other hand, green infrastructure allow for a more natural absorption of precipitation and stormwater into the ground, slower movement of such water over the surface of the earth due to vegetated ditches and waterways, as well as evaporation and evapotranspiration by vegetation (Zellner, Massey, Minor, \& Gonzalez-Meler, 2016). Green infrastructure can be designed at large-scale levels such as neighborhoods, or small-scale levels like individual property lots. Implementing green infrastructure on privately owned property can actually be significantly easier, as the site generally has less constraints and construction cost can be cheaper (Natural Resources Defense Council (NRDC) and the New York University Stern School of Business' Center for Sustainable Business (NYU Stern CSB), 2017). These designs can include green roofs, bioswales, permeable pavement, and infiltration trenches at a scale that can be applied to individual property lots (Coleman, Hurley, Rizzo, Koliba, \& Zia, 2018; Mughal, Ross, \& Fearon, 2017).

Future projections indicate that the Houston area, along with many other coastal areas, may suffer more severe flood events more regularly in the future (Russell, Risser, Smith, \& Kunkel, 2019). Understanding the linkages between green infrastructures, ethnicity, and education may help policy makers design public policies that distribute the benefits of green infrastructures across all segments of our society.

\section{LITERATURE REVIEW}

Since the emergence of the sustainability agenda in the mid-1980s, cities have become a primary location for sustainability implementation, including the installation, maintenance, and retrofitting of green infrastructure (Council, 2009). Scholars have assessed the viability of these systems both internationally (Douglas, 2018; Ferguson, Roberts, McEachan, \& Dallimer, 2018) and within the United States including Baltimore (Baker, Brenneman, Chang, McPhillips, \& Matsler, 2019), Detroit (Meerow \& Newell, 2017; Schilling \& Logan, 2008), Philadelphia (Mandarano \& Meenar, 2017), Portland (Baker et al., 2019; Shandas, 2015), Syracuse, New York (Baptiste, Foley, \& Smardon, 2015), and Tampa, Florida (Wendel, Downs, \& Mihelcic, 2011).

Dunn (2010) argues that green infrastructure ought to be placed in poverty stricken urban areas in order to improve urban water quality, reduce urban air pollution, improve energy efficiency, beautify neighborhoods, and lower crime rates. She also argues that installing green infrastructures will provide jobs during installation, and provide locales for growing local produce. Additionally, Dunn (2010) points out that green infrastructures may help cities meet federal government mandates under the Clean Water Act along with a plethora of state and local regulations that have required cities to include green infrastructure projects as part of water quality initiatives.

Wendel et al. (2011) found that the installation of green infrastructures within cities was not equally accessible to minorities when they compared the cities of Tampa and East Tampa. They also make a distinction between ease of access and the quality of the urban green space. Factors that may impact the unequal distribution of green infrastructures within cities include ethnicity, education level, and wealth (or lack thereof). Each of these three facets are examined in more detail in the following sections. It is important to note that very few of the studies provide consistent definitions as far as what constitutes green infrastructures. For this reason, the literature review focuses on scholarly works that contain either green infrastructure or a combination of green infrastructure and traditional stormwater infrastructure, but not solely open spaces.

\section{Ethnicity}

Opp, Osgood Jr, and Rugeley (2014) conducted a survey of United States cities in order to identify correlations between demographic characteristics and the implementation of sustainable environmental policies. They find that large cities with more highly educated residents, a higher percentage of Hispanic residents, and in the western region of the United States are more likely to implement sustainable policy. While Opp et al. (2014) do not specifically mention green infrastructure, several other categories measure "environmentally friendly development" and green infrastructures could be included within this measure. Additionally, this study does include grey stormwater and reclaimed water recycling as one of the sustainable environmental policies. While these results include survey data from across the country, this study does not look at linkages between environmental policy implementation and demographic characteristics within a singular city as part of this methodology. It nevertheless provides a useful starting point for forming hypothesis about green infrastructure and ethnicity, in particular.

Chan and Hopkins (2017) found a positive correlation between minorities and green infrastructure in Portland. However, the authors believe this is due to a specific Portland policy that required the diffusion of green infrastructure projects throughout the city. Mandarano and Meenar (2017) however, found the opposite with a negative cor- 
relation between Hispanics and green infrastructure in Philadelphia. More recently, Baker et al. (2019) did not find a correlation between race and green infrastructure density in Baltimore.

\section{Education}

Shandas (2015) surveyed residents in Portland, Oregon in order to identify factors that led to residents supporting the adoption of green infrastructure prior to the city of Portland implementing a city-wide green infrastructure project. Shandas (2015) determined that survey participants with higher levels of formal education were more likely to be interested in the implementation of green infrastructure. This was supported by Shadas' findings that residents' perceptions about the usefulness of green infrastructure decreased when outreach and other educational sources about stormwater management decreased. This correlation suggests that education about stormwater management is a critical factor in the resident's acceptance and support of such features. However, when Chan and Hopkins (2017) analyzed actual census block data for Portland, they found a negative correlation between the presence of a Bachelor's degree and green stormwater infrastructure.

\section{Green Infrastructure and Poverty}

Muttarak and Lutz (2014) directly credit education in having an important role in individuals gaining the competency, knowledge, and skills needed in order to influence the ability to adapt to hazardous situations. Additionally, education is generally associated with socioeconomic status, seeing as education tends to increase earnings (Psacharopoulos \& Patrinos, 2004). As such, this would allow for individuals to be capable of implementing green infrastructure to lower flooding risk in their area (Muttarak \& Lutz, 2014). However, when Chan and Hopkins (2017) explored the relationship between income and green stormwater infrastructure in Portland, they found a negative correlation.

\section{Theoretical Statement}

This paper seeks to confirm the hypothesis as derived from the existing literature dealing with the relationship between green infrastructure, ethnicity, education level, and wealth in flood prone cities that have been and will continue to be threatened with major flood events such as hurricanes. Given the current lack of consensus among scholars documented above, this research hopes to provide more evidence in the search for understanding about the causes of sustainable environmental policy adoption and implantation, especially concerning green infrastructures.

\section{Research Model}

After reviewing scholarly works mentioned above, we derive the following hypothesis:

(1) School districts with high educational rates should see a correspondingly high rate of green infrastructure.

(2) School districts with a higher concentration of wealth should see higher rates of green infrastructure.

(3) School districts with high concentration of Hispanic population should see a correspondingly high rate of green infrastructure.

We now turn towards an explanation of our methodology for testing these hypotheses.

\section{METHODS}

The green infrastructures identified in this study consisted of detention ponds, retention ponds, infiltration basins, bioswales, and wetland channels, as defined by the Environmental Protection Agency \& American Society of Civil Engineers (2002). Detention ponds were defined as basins that hold stormwater runoff and empty sometime after the runoff event has ended, while retention ponds contain some amount of water year-round and do not have any sort of outflow structure. This research defined an infiltration basin as a depression that captures stormwater and infiltrates it into the ground. It is commonly lined with rocks or other highly permeable sediments. Bioswales were identified as channels lined with grass that allows for shallow flow near the origin of surface runoff. The green infrastructures within this study was limited to those that could be identified through the use of Google Earth's street view function. This eliminated the potential of identifying porous pavements, rain gardens, and rain barrels or cisterns.

Green infrastructure data for each school district area was gathered using Google Earth. Shifting the level analysis from the census tract to the independent school district allows us to contemplate whether education about green infrastructure in the public schools impacts the spatial distribution and access to green infrastructure in the immediate vicinity.

Under the U.S. Government layer in Google Earth, the school boundary locations were enabled to appear on the imagery. Furthermore, each district was investigated on a block by block basis in order to locate green infrastructures. Once a feature was determined to meet the criteria required, a pinpoint was added to the satellite imagery in the specific location of the feature and tagged with a corresponding number. Seeing as the study locations included altogether some 254 miles of land, polygons were added to the imagery in areas which had already been inspected in order to prevent confu- 
sion between areas that simply lacked green infrastructures and areas that had not yet been examined.

Once the entire area of a school district had been assessed, the folder within Google Earth that contained all of the determined data points, was saved as a Keyhole Markup Language (KML) file. Changing the data to this file type allowed for a simple transfer of data into the ArcGIS 10.6 mapping program. This program allowed for a wider variety of options for the way data could be handled and presented than those available in Google Earth.

The particular part of the program suite used was ArcMap. Once in ArcMap, the appearance of the data points was changed to prevent the overlapping of location markers and a background map was added to provide satellite imagery. A geodatabase file downloaded from the GIS database page of the Houston-Galveston Area Council (HGAC) was used to mark the school district boundary on ArcMap, as the school district boundaries previously provided in Google
Earth could not be saved and moved to other programs. Because the data imported into ArcMap and the data provided by Houston-Galveston Area Council (2014) were not in the same geographical coordinate system as the background imagery, they had to be projected into World Geodetic System (WGS) of 1984, a commonly used datum for modeling the earth's surface (Law \& Collins, 2015).

The steps previously described, from the gathering of data to the importation of that data into ArcMap, was then performed for the two other school districts. Following the creation of these three individual maps, another map was created which indicated the school district locations within the greater Houston metropolitan area using the previously downloaded school district location data and location data for the Houston metropolitan areas. This data was also obtained from Houston-Galveston Area Council (2014).

Figure 1 shows the study area involving three school districts in the Houston Galveston Metropolitan Area in Texas.

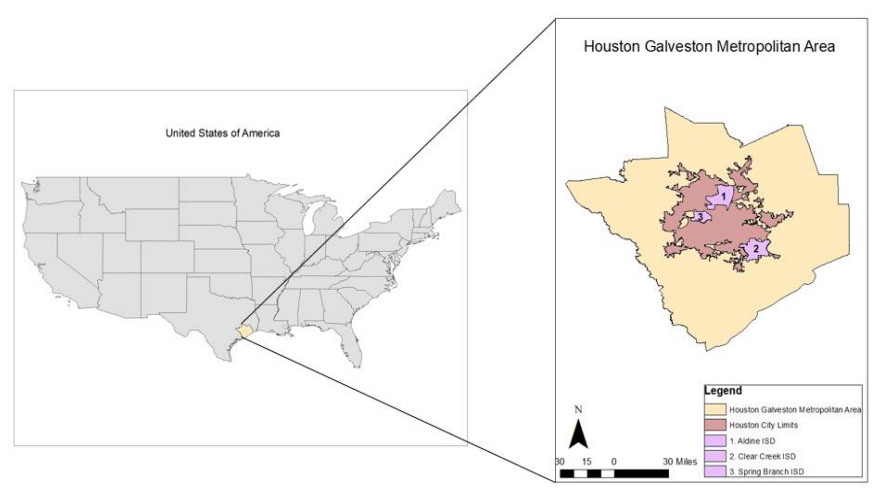

FIGURE 1. Houston Galveston metropolitan area in Texas (Source: (National Oceanic Atmospheric Administration, 2018))

These schools were selected based on the percentage of students who were eligible for the National School Lunch Program (NSLP). According to the Texas Education Agency (2018), in the 2010-2011 school year around $23.0 \%$ of secondary students in Clear Creek Independent School District (ISD) met criteria for the free lunch program. That same year $73.3 \%$ of secondary students in Aldine ISD and $49.4 \%$ of secondary students in Spring Branch ISD also met qualifications for the NSLP. Eligibility of the NSLP was determined by the state of Texas based on low household income data combined with the number of residents in the household. Additionally, by being already enrolled in the Temporary Assistance for Needy Families, foster care, Head Start, Food Distribution Program on Indian Reservations, or the Supplemental Nutritional Assistance Program, students would meet categorical eligibility for the NSLP (Texas Benefits, n.d.). The U.S. Census Bureau provided data regarding the educational attainment (U.S. Census Bureau, 2017b) and poverty levels (U.S. Census Bureau, 2017c) for the school districts. These descriptive statistics were then compared to the number of green infrastructures identified in each school district.

Due to the inconclusive nature of the results, further analysis was conducted to understand the concentration of green infrastructures in some areas. National Land Coverage Database (NLCD) data was obtained from Esri (2014) in order to determine if the occurrence of green infrastructures was occurring due to the amount of concrete and other impervious surfaces within each school district. Each cell within the raster data represents 30 meters of ground coverage. Once the NLCD raster data was clipped to only appear within the boundaries of the school districts, the categories of imperviousness observed in the raster dataset were combined to create five categories. These five layers were chosen as an easier way to view the data. After the data had been broken down into five categories, the spatial analysis was run on each school district to determine the amount of each category of impervious land coverage 
was present. The project team utilized the zonal histogram function that calculates the frequency distribution of percentages or other values based on their location. This tool allowed for the total number of raster points with values between $0-20 \%$ within each school district to be summed and turned into a percentage to represent the amount of the school district which was covered in between 0-20\% impervious land coverage (Esri Online, 2016).

\section{DATA ANALYSIS}

As Table 1 indicates, education rates for residents with a high school degree or higher increased for the population between the ages of 18-24 years of age in Aldine ISD, but maintained the lowest educational attainment rates of the three districts studied. Despite that, the educational attainment rate in this district has increased by almost $10 \%$ from the older of the two age groups.

TABLE 1. Educational attainment by age

\begin{tabular}{lllllll}
\hline \hline \multirow{2}{*}{ Educational Attainment by Age } & \multicolumn{2}{c}{ Aldine ISD } & \multicolumn{2}{c}{ Clear Creek ISD } & \multicolumn{2}{c}{ Spring Branch ISD } \\
\cline { 2 - 7 } & Number & Percent & Number & Percent & Number & Percent \\
\hline Population age 18-24 years & 29,237 & $(\mathrm{X})$ & 20,926 & $(\mathrm{X})$ & 13,883 & $(\mathrm{X})$ \\
High school graduate or higher & 21,916 & 75.0 & 17,958 & 85.8 & 10,802 & 77.8 \\
Population age 25 years \& above & 167,932 & $(\mathrm{X})$ & 151,488 & $(\mathrm{X})$ & 120,637 & $(\mathrm{X})$ \\
High school graduate or higher & 108,210 & 64.6 & 142,005 & 93.7 & 97,395 & 80.7 \\
\hline \hline
\end{tabular}

Note: This table displays the educational attainment based on age within Aldine, Clear Creek, and Spring Branch ISDs (U.S. Census Bureau, 2017b).

The district with the highest education rates was in Clear Creek ISD in both the population between the ages of 18-20 years and the population for the age of 25 years and above. This district had the next largest rate of change between education attainment in the population age 18-20 years and age 25 years and above, at $7.9 \%$. The final school district, Spring Branch ISD, fell between the highest and the lowest rates of educational attainment and had the smallest rate of change between the two population groups at $2.9 \%$ in any district.

Table 2 shows that while, the poverty level in Aldine ISD was the highest, at $18.2 \%$, within the school districts studied, it also had the largest population.

TABLE 2. Poverty level on educational attainment

\begin{tabular}{|c|c|c|c|}
\hline \multirow[t]{2}{*}{ Poverty Level Based on Educational Attainment } & Aldine ISD & Clear Creek ISD & Spring Branch ISD \\
\hline & Estimate & Estimate & Estimate \\
\hline Total & 183,844 & 154,499 & 120,949 \\
\hline Income in the past 12 months below poverty level & 33,419 & 11,084 & 14,660 \\
\hline Less than high school graduate & 18,022 & 1,766 & 6,641 \\
\hline High school graduate (includes equivalency) & 7,937 & 3,208 & 2,366 \\
\hline Some college, associate's degree & 5,600 & 3,219 & 3,323 \\
\hline Bachelor's degree or higher & 1,860 & 2,891 & 2,330 \\
\hline Income in the past 12 months at or above poverty level & 150,425 & 143,415 & 106,289 \\
\hline Less than high school graduate & 46,525 & 7,928 & 16,246 \\
\hline High school graduate (includes equivalency) & 47,038 & 24,027 & 15,751 \\
\hline Some college, associate's degree & 37,019 & 44,909 & 20,228 \\
\hline Bachelor's degree or higher & 19,843 & 66,551 & 54,064 \\
\hline Overall Poverty Rate & $18.2 \%$ & $13.9 \%$ & $8.25 \%$ \\
\hline
\end{tabular}

Note: This table displays the data regarding poverty levels within Aldine, Clear Creek, and Spring Branch ISDs based on educational attainment levels (U.S. Census Bureau, 2017c).

Clear Creek ISD held the intermediate poverty rate at $13.9 \%$ and the poverty rate in Spring Branch ISD was $8.25 \%$. The expected trend of individuals with less than a high school degree having the highest levels of poverty was supported by this data and as the overall amount of education attained increased, the poverty level decreases.

Table 3 reveals that the total number of observable green infrastructures varied greatly throughout the three school districts. 
TABLE 3. Number of green infrastructures

\begin{tabular}{llll}
\hline \hline Total GIs & Aldine ISD & Clear Creek ISD & Spring Branch ISD \\
\hline Total GIs & 2115 & 765 & 1182 \\
Total Area of District in $m i^{2}$ & 109 & 105 & 41 \\
GI per $m i^{2}$ & 19.4 & 7.3 & 28.8 \\
\hline \hline
\end{tabular}

Note: This table displays the number of Green Infrastructures (GI) present within Aldine, Clear Creek, and Spring Branch ISDs. This also shows the size of each school district (Houston-Galveston Area Council, 2014), as well as the number of green infrastructures present per mile.

While the Aldine ISD area had a significantly larger number of green infrastructures than the other two districts, it did not have the highest rate of green infrastructures per mile. Spring Branch ISD had approximately 28.8 green infrastructures for every mile of land. Clear Creek ISD had the lowest number of green infrastructures and the smallest rate of green infrastructures per mile at 7.3.

Table 4 shows Aldine ISD has the highest percentage of Hispanic or Latino/a population; concurrently, Figure 2 provides a visualization for the density of green infrastructures within the portion of the school districts indicating the high density of green infrastructures in Aldine ISD.

TABLE 4. Ethnic composition

\begin{tabular}{llllll}
\hline \hline School District & \% White & \% Black & \% Hispanic or Latino & \% Asian & \% Two or More Races and Others \\
\hline Aldine & 9 & 26 & 62 & 2 & 1 \\
Clear Creek & 61 & 8 & 20 & 9 & 3 \\
Spring Branch & 43 & 4 & 44 & 7 & 1 \\
\hline \hline
\end{tabular}

Note: This table indicates the ethnicities that make up Aldine, Clear Creek, and Spring Branch ISDs, including their corresponding percentages (National Center for Education Statistics, n.d.).
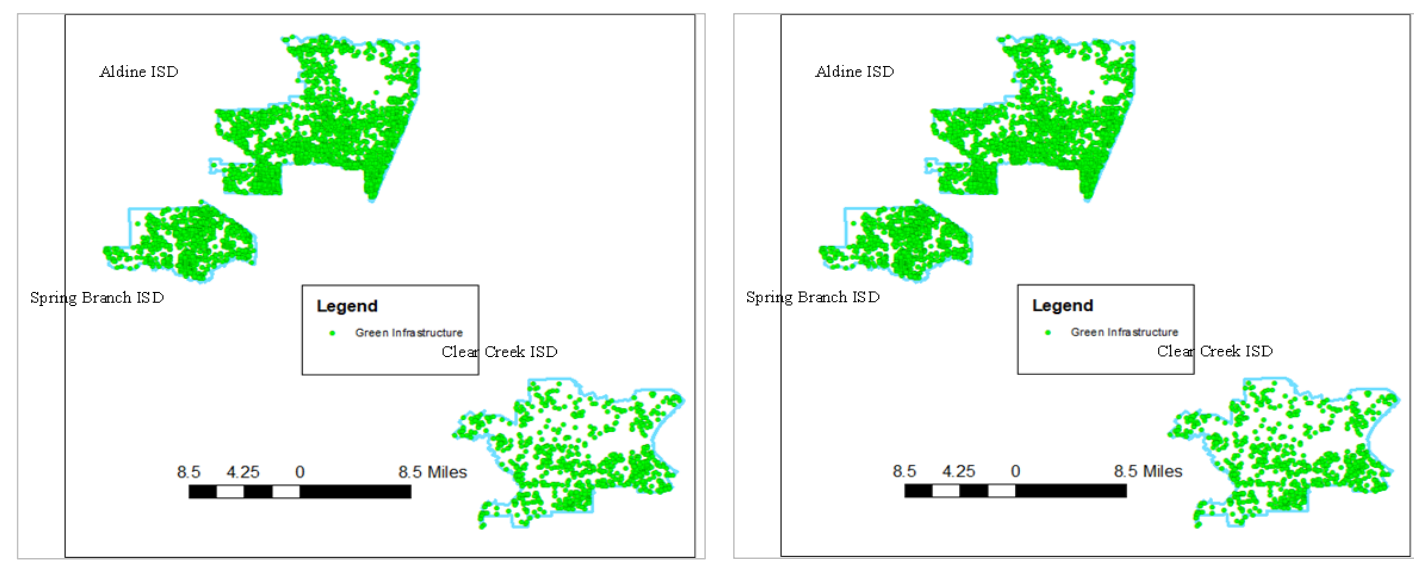

FIGURE 2. Locations of green infrastructures within Aldine, clear creek, and spring branch ISDs

The area in the north central section of Aldine ISD that was largely barren of green infrastructures occurs as a result of an aggregation of air strips that was identified using Google Earth. A similarly barren area of Spring Branch ISD existed within its northeastern corner. This barren area forms Addicks Reservoir, one of Houston's large flood control detention basins. When the area is not acting to detain flood water, it doubles as parks and other green spaces. Another bare area can also be noted along the central portion of the eastern border of Clear Creek ISD, known as Clear Lake. This location contains a water inlet that houses multiple bays.

Table 5 displays the amount of land covered by different levels of impervious land coverage, as determined by the spatial analysis completed using the ArcGIS program. 
TABLE 5. Impervious land coverage

\begin{tabular}{lllllll}
\hline \hline School District & \multicolumn{2}{c}{ Aldine ISD } & \multicolumn{2}{c}{ Clear Creek ISD } & \multicolumn{2}{c}{ Spring Branch ISD } \\
\hline Percent Coverage Categories & Cell Count & Percent & Cell Count & Percent & Cell Count & Percent \\
\hline $0-20$ & 120274 & 40.41 & 152529 & 53.49 & 24052 & 21.50 \\
$20.001-40$ & 40467 & 13.60 & 30878 & 10.83 & 24814 & 22.18 \\
$40.001-60$ & 50754 & 17.05 & 43846 & 15.38 & 24937 & 22.29 \\
$60.001-80$ & 45289 & 15.22 & 38529 & 13.51 & 17815 & 15.92 \\
$80.001-100$ & 40876 & 13.73 & 19353 & 6.79 & 20252 & 18.10 \\
Total & 297660 & 100.00 & 285135 & 100.00 & 111870 & 100.00 \\
\hline \hline
\end{tabular}

Note: This table displays the amount of impervious land coverage in Aldine, Clear Creek, and Spring Branch ISDs. Each cell represents 30 meters of ground coverage and is defined by how much of the land within that cell is covered by impervious surfaces. These numbers were then put into percentages for easier comparison.

The impervious land coverage analysis did not indicate a consistent pattern regarding the relationship between the number of green infrastructures present within the school district to the amount of land that was covered with impervious surfaces. Because this data was in raster form, a value was assigned to each cell, indicating how much of the land within the 30 meter area was covered by impermeable surfaces. When combining the $60-80 \%$ and the $80-100 \%$ coverage categories, it is quite clear that Clear Creek had the least amount of areas highly covered by impervious sur- faces. These two categories combined only accounted for $20.3 \%$ of land coverage within Clear Creek ISD. However, when combining the same categories of impervious land coverage for Aldine ISD and Spring Branch ISD, it is noted that they had an elevated level of land covered by impervious surfaces at $28.95 \%$ and $34.02 \%$, respectively.

Figure 3 provides a visualization displaying the amount that each category of impervious surfaces covered the land within each school district.

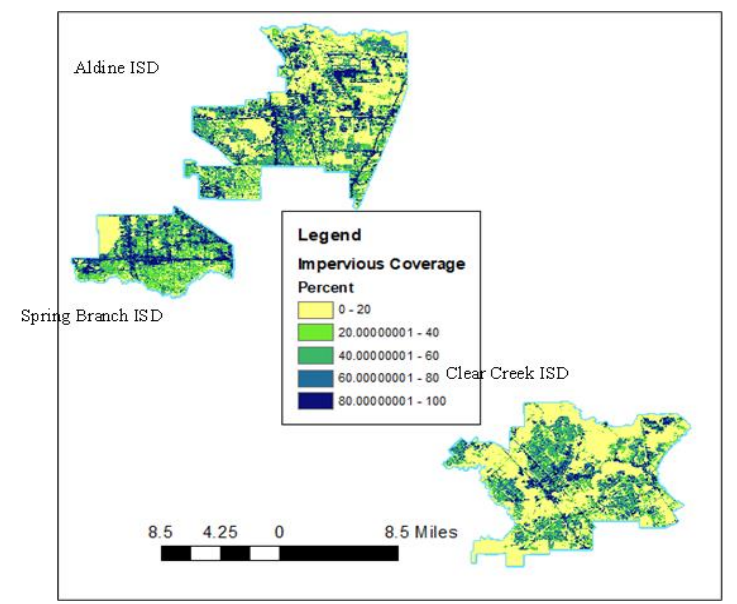

FIGURE 3. Percentage of impervious land cover within Aldine, clear creek, and spring branch ISDs

Similarly to Figure 2, Figure 3 displayed the location of the impervious coverage of the air strips in the north central area of Aldine ISD with the dark blue color, indicating 80-100\% impervious land coverage, while to the south east of the air strips it was evident that largely undeveloped areas remain. Again, in correspondence to the northwestern area of Spring Branch ISD that did not have any green infrastructures, it is noted how this area contains 0-20\% impervious land coverage, while the remainder of Spring Branch ISD was somewhat densely covered in impervious surfaces. The areas within Clear Creek ISD that lacked green infrastructures could more easily be identified here, as there was a sharp boundary of impervious surfaces along the lake and bays. However, the small amount of blue present within the Clear Creek ISD area made it easy to determine that this district had less widely and heavily developed areas when compared to Aldine ISD or Spring Branch ISD.

\section{DISCUSSION}

Our research results conflict with the results found by Derkzen, van Teeffelen, and Verburg (2017) and Shandas (2015). While both of these studies presented compelling evidence that education level and socioeconomic status determine the willingness to implement green infrastructure, 
they did not correspond with the number of green infrastructures in place in the Houston metropolitan area. Our results indicated that Aldine ISD, the school district with the lowest level of educational attainment and was the most socioeconomically deprived, held the highest number of green infrastructures among the three school districts when normalized in accord to the size of the school districts.

A combination of geographic factors should be considered when investigating the locations of green infrastructure in Houston. First, Houston is one of the only major cities within the United States that does not have any zoning laws (Feagin, 1985). This combined with the excessive population growth that Houston has undergone creates many difficulties, and has led to circumstances that are favorable for urban flooding (Loughran, Elliott, \& Kennedy, 2019).

The population of Houston has expanded by at least $29 \%$ every decade since the 1850 's, with some periods experiencing exponential growth. A population growth of $111 \%$ occurred between 1920-1930 (Feagin, 1985). A large portion of this growth is due to Houston's easy access to international trade via the Houston Ship Channel and the expansion of the oil industry with nearby oil fields, which resulted in a growing petrochemical industry on the east side of the city (Cook, 2017). Upscale neighborhoods developed in the Western portion of the city with large houses on spacious lots. Thanks to deed restrictions, these areas have seen little redevelopment. Between the affluent neighborhoods and the port, the inner city was home to the working class, therefore reducing their commute costs to the port (Mieszkowski \& Smith, 1991).

The combination of the high paced expansion of the city and the lack of zoning laws meant that as the city grew, it could expand towards the suburbs instead of redeveloping the downtown and inner-city areas (Mieszkowski \& Smith, 1991). Another short fall resulting from the lack of zoning laws was the development of housing in whatever land was available near the city, even if it meant developing in a flood zone (Texas General Land Office, 2018). Seeing as these were low income residential areas, the lack of adequate utilities and infrastructures, such as sewage and storm systems, would require a substantial amount of public funds to enhance them (Mieszkowski \& Smith, 1991).

However, Harris County has been trying to rectify some of these problems over the last few decades by implementing a buyout program to get citizens out of the areas which routinely flood and cause structural and property damage. Since 1985, the Harris County Flood Control District (Harris County Flood Control District, 2018) has bought approximately 3,000 houses from residents that flood repeatedly due to their location deep within the flood plain. While this program occurs within Harris County, the vast majority of the funds provided to buyout intermittently flooded properties is drawn from multiple federal programs that exist under Federal Emergency Management Agency, as well as funds provided by the U.S. Department of Housing and Urban Development (Harris County, 2018a).

Many of these programs are aimed specifically at low and moderate income residents who may be at risk for future flooding, especially those at $30 \%$ below the median income of the area. These programs help to get residents into housing areas that are at less risk of future disasters (Harris County, 2018b). Once the property has been purchased, the lot will be cleared and either remain an open lot for floodplain conservation or excavation will occur for detention of flood waters. Furthermore, it is a common theme in the literature that those who are most vulnerable to disasters are those of lower education and socioeconomic status (Cutter et al., 2003). This is evident in when comparing locations of the homes that have been part of the federal buyout program. Since the program began approximately 228 buyouts have occurred in the Aldine ISD area compared to 33 buyouts in the Spring Branch ISD area and 52 buyouts in the Clear Creek ISD Area (ProPublica, 2018).

Another significant factor in the amount of flooding that occurs is the extent of impervious area within the school district. Evidence from Table 5 and Figure 3 indicate that Aldine ISD has more impervious land coverage area when measured in square meters than either Clear Creek ISD or Spring Branch ISD. This translates to more stormwater runoff. Not only is this area already subject to flooding due to its geographic location and urbanization patterns, it also shows ethnic boundary formation patterns in the area. The association between the highest percentage of Hispanics in Aldine ISD and the green infrastructure density could be associated with the Hispanic population's income level and the less expensive cost of housing in the flood zone. This research did not attempt to ascertain the linkage between Hispanic population's preferences for green infrastructure due to environmental conscious choices.

Unlike some previous study results, Houston's green infrastructure in poor neighborhoods occurs as a consequence from previous flood events. Houston's green infrastructures appear to have been created due to buyouts after past flood events. This stands in stark contrast to Portland's approach of implementing green infrastructure for its environmental benefits. 


\section{CONCLUSION}

Previous studies failed to address the implementation of green infrastructure based on education level and socioeconomic status in an area that is highly prone to hydrological disasters, such as hurricanes and significant flooding. This study fills the gap in the literature by focusing on areas which desperately need these structures because of its low elevation and adjacent location to hurricane prone coastal areas, delivered different results than those of previous studies due to geographic specificity. Within Houston, Texas areas that have lower education levels and are socioeconomically disadvantaged have more green infrastructures present than those of higher education levels and well off socioeconomic areas.

These results indicate that the implementation of green infrastructure throughout the city of Houston is not uniform. While Aldine ISD has numerous factors that contribute to the need for more green infrastructures in this area, it is evident that multiple ways to help remediate the continually devastating flooding is through different policy inclusions. The first policy recommendation is to provide city-wide incentives that will help residents to justify spending money on green infrastructures. One possible incentive includes discounting sewage fees in exchange for new green infrastructure installations.

The second policy recommendation includes the addition of educational sessions to be held at public locations, like libraries, on a regular basis that would allow residents to determine if they live within a flood plain. These information sessions could also introduce ways for residents to prepare their properties for potential flooding, including different green infrastructure types, as well as educate them about the previously mentioned incentivized implementa- tion plan. Considering a sizable portion of the residents impacted by flooding are of Hispanic ethnicity, it would be more convenient for Spanish speakers if these information sessions were held in English and Spanish. The authors note that the City of Houston operates CitizensNet, an email distribution system (City of Houston, 2019). We would recommend including this type of information in the CitizensNet email in both English and Spanish.

\section{LIMITATIONS AND RECOMMENDATIONS}

A weakness of this study was the lack of socioeconomic and education data on a smaller level, like census tract or census block group, similar to that seen in Baker et al. (2019). This could potentially show a more accurate correlation between socioeconomic status, education level and the location of green infrastructures. Another shortcoming involves the lack of the inclusion of topographical features within the school districts' boundaries. Topographic features like soil type and flood plain location can affect the amount of green infrastructure needed depending on soil characteristics, infiltration rate, and the location and extent of flood plains. Other features like slope, elevation and vegetation type and coverage also contribute to runoff rates and volumes (Sarkar, Butcher, Johnson, \& Clark, 2018).

In order to further this study, it is crucial to collect data from Aldine, Clear Creek, and Spring Branch ISDs to determine if the schools use curriculum in teaching environmental science that includes topics pertinent to our study such as climate change, localized flooding, and green infrastructures. This addition of survey data to test if school districts with a higher concentration of green infrastructure are more likely to understand the benefits of green infrastructure could potentially solidify our current findings.

\section{REFERENCES}

Baker, A., Brenneman, E., Chang, H., McPhillips, L., \& Matsler, M. (2019). Spatial analysis of landscape and sociodemographic factors associated with green stormwater infrastructure distribution in Baltimore, Maryland and Portland, Oregon. Science of the Total Environment, 664, 461-473. doi:https://doi.org/10.1016/j.scitotenv.2019.01.417

Baptiste, A. K., Foley, C., \& Smardon, R. (2015). Understanding urban neighborhood differences in willingness to implement green infrastructure measures: A case study of Syracuse, NY. Landscape and Urban Planning, 136, 1-12. doi:https:// doi.org/10.1016/j.landurbplan.2014.11.012

Chan, A. Y., \& Hopkins, K. G. (2017). Associations between sociodemographics and green infrastructure placement in Portland, Oregon. Journal of Sustainable Water in the Built Environment, 3(3), 1-7. doi:https://doi.org/10.1061/ JSWBAY.0000827

City of Houston. (2019). Citizensnet. Retrieved from http://www .houstontx . gov/citizensnet/

Coleman, S., Hurley, S., Rizzo, D., Koliba, C., \& Zia, A. (2018). From the household to watershed: A cross-scale analysis of residential intention to adopt green stormwater infrastructure. Landscape and Urban Planning, 180, 195-206. doi: https://doi.org/10.1016/j.landurbplan.2018.09.005 
Cook, S. C. (2017). The audacious launch of the city of Houston: Capital of the Republic of Texas. Southwestern Historical Quarterly, 121(2), 122-144. doi:https://doi.org/10.1353/swh.2017.0051

Council, N. R. (2009). Urban stormwater management in the United States. Washington, DC: The National Academies Press.

Cutter, S. L., Boruff, B. J., \& Shirley, W. L. (2003). Social vulnerability to environmental hazards. Social Science Quarterly, 84(2), 242-261. doi:https://doi.org/10.1111/1540-6237.8402002

Davis, A. P., \& McCuen, R. H. (2005). Stormwater management for smart growth. New York City, NY: Springer.

Derkzen, M. L., van Teeffelen, A. J., \& Verburg, P. H. (2017). Green infrastructure for urban climate adaptation: How do residents' views on climate impacts and green infrastructure shape adaptation preferences? Landscape and Urban Planning, 157, 106-130. doi:https://doi.org/10.1016/j.landurbplan.2016.05.027

Dhakal, K. P., \& Chevalier, L. R. (2016). Urban stormwater governance: The need for a paradigm shift. Environmental Management, 57(5), 1112-1124. doi:https://doi.org/10.1007/s00267-016-0667-5

Douglas, I. (2018). The challenge of urban poverty for the use of green infrastructure on floodplains and wetlands to reduce flood impacts in intertropical Africa. Landscape and Urban Planning, 180, 262-272. doi:https://doi.org/10.1016/ j.landurbplan.2016.09.025

Dunn, A. D. (2010). Siting green infrastructure: legal and policy solutions to alleviate urban poverty and promote healthy communities. Boston College Environmental Affairs Law Review, 37, 41-66.

Environmental Protection Agency \& American Society of Civil Engineers. (2002). Urban stormwater BMP performance monitoring: A guidance manual for meeting the national stormwater BMP database requirements. Washington, DC, WA: US Environmental Protection Agency.

Esri. (2014). USA NLCD impervious surface 2011. Retrieved from https://bit.1y/39Fdc6B

Esri Online. (2016). An overview of the spatial analyst toolbox. Retrieved from https://bit.1y/2QRhRK7

Feagin, J. R. (1985). The global context of metropolitan growth: Houston and the oil industry. American Journal of Sociology, 90(6), 1204-1230. doi:https://doi.org/10.1086/228208

Ferguson, M., Roberts, H., McEachan, R., \& Dallimer, M. (2018). Contrasting distributions of urban green infrastructure across social and ethno-racial groups. Landscape and Urban Planning, 175, 136-148. doi:https://doi.org/10.1016/ j.landurbplan.2018.03.020

Harris County. (2018a). Disaster recovery voluntary buyout program guidelines. Retrieved from https://bit. ly/36xcshL Harris County. (2018b). Draft Harris county supplemental action plan. Retrieved from https://bit.1y/2rZCpYf

Harris County Flood Control District. (2018). Hurricane harvey impact and response in Harris county. Retrieved from https://bit.1y/2s2eZ4H

Houston-Galveston Area Council. (2014). Designing for impact: A regional guide to low impact development. Retrieved from https://bit.1y/2QwFzfq

Khan, S. D. (2005). Urban development and flooding in Houston Texas, inferences from remote sensing data using neural network technique. Environmental Geology, 47(8), 1120-1127. doi:https://doi.org/10.1007/s00254-005-1246-x

Kousky, C., Olmstead, S. M., Walls, M. A., \& Macauley, M. (2013). Strategically placing green infrastructure: Cost-effective land conservation in the floodplain. Environmental Science \& Technology, 47(8), 3563-3570. doi:https://doi.org/10.1021/ es303938c

Law, M., \& Collins, A. (2015). Getting to know ArcGIS: For ArcGIS 10.2 and 10.3. Redlands, CA: Esri Press.

Loughran, K., Elliott, J. R., \& Kennedy, S. W. (2019). Urban ecology in the time of climate change: Houston, flooding, and the case of federal buyouts. Social Currents, 6(2), 121-140. doi:https://doi.org/10.1177/2329496518797851

Mandarano, L., \& Meenar, M. (2017). Equitable distribution of green stormwater infrastructure: A capacity-based framework for implementation in disadvantaged communities. Local Environment, 22(11), 1338-1357. doi:https://doi.org/ $10.1080 / 13549839.2017 .1345878$

Marobhe, M., \& Hembe, L. (2019). The nexus between dividend policy and financial gearing of listed non financial companies in Tanzania. International Journal of Business and Administrative Studies, 5(5), 294-302. doi:https://dx.doi.org/10 .20469/ijbas.5.10004-5

Mays, L. W., \& Tung, Y.-K. (1992). Hydrosystems engineering and management. New York City, NY: McGraw-Hill, Inc.

Meerow, S., \& Newell, J. P. (2017). Spatial planning for multifunctional green infrastructure: Growing resilience in Detroit. Landscape and Urban Planning, 159, 62-75. doi:https://doi.org/10.1016/j.landurbplan.2016.10.005 
Mieszkowski, P., \& Smith, B. (1991). Analyzing urban decentralization: The case of Houston. Regional Science and Urban Economics, 21(2), 183-199. doi:https://doi.org/10.1016/0166-0462(91)90033-J

Mughal, M. S., Ross, A. D., \& Fearon, D. J. (2017). Development needs of middle managers in higher education institutions: A case study of a post 1992 New University in UK. International Journal of Business and Administrative Studies, 3(6), 239-259. doi:https://doi.org/10.20469/ijbas.3.10005-6

Muttarak, R., \& Lutz, W. (2014). Is education a key to reducing vulnerability to natural disasters and hence unavoidable climate change? Ecology and Society, 19(1), 1-8. doi:https://doi.org/10.5751/ES-06476-190142

National Center for Education Statistics. (n.d.). Education demographic and geographic estimates. Retrieved from https: // bit. $1 \mathrm{y} / 2 \mathrm{sVt} 4 \mathrm{RH}$

National Oceanic and Atmospheric Administration. (2019). Houston IAH extremes, normals, and annual summaries. Retrieved from https://bit.ly/2sWB599

National Oceanic Atmospheric Administration. (2018). U.S. states (Generalized). Retrieved from https : //bit. ly/39POuR9

Natural Resources Defense Council (NRDC) and the New York University Stern School of Business' Center for Sustainable Business (NYU Stern CSB). (2017). Catalyzing green infrastructure on private property: Recommendations for a green equitable, and sustainable New York City. Retrieved from https://on.nrdc.org/2N3qlf V

Opp, S. M., Osgood Jr, J. L., \& Rugeley, C. R. (2014). Explaining the adoption and implementation of local environmental policies in the United States. Journal of Urban Affairs, 36(5), 854-875. doi:https://doi.org/10.1111/juaf.12072

ProPublica. (2018). Harris county flood control district buyout data. Retrieved from https://bit.1y/35o4GFG

Psacharopoulos, G., \& Patrinos, H. A. (2004). Returns to investment in education: A further update. Education Economics, 12(2), 111-134. doi:https://doi.org/10.1080/0964529042000239140

Russell, B. T., Risser, M. D., Smith, R. L., \& Kunkel, K. E. (2019). Investigating the association between late spring Gulf of Mexico sea surface temperatures and US Gulf Coast precipitation extremes with focus on Hurricane Harvey. Environmetrics, Just accepted, 1-14. doi:https://doi.org/10.1002/env.2595

Sarkar, S., Butcher, J. B., Johnson, T. E., \& Clark, C. M. (2018). Simulated sensitivity of urban green infrastructure practices to climate change. Earth Interactions, 22(13), 1-37. doi:https://doi.org/10.1175/EI-D-17-0015.1

Schilling, J., \& Logan, J. (2008). Greening the rust belt: A green infrastructure model for right sizing America's shrinking cities. Journal of the American Planning Association, 74(4), 451-466. doi:https://doi.org/10.1080/01944360802354956

Shandas, V. (2015). Neighborhood change and the role of environmental stewardship: A case study of green infrastructure for stormwater in the City of Portland, Oregon, USA. Ecology and Society, 20(3), 1-17. doi:https://doi.org/10.5751/ ES-07736-200316

Sonne, B. (2014). Managing stormwater by sustainable measures: Preventing neighborhood flooding and green infrastructure implementation in New Orleans. Tulane Environmental Law Journal, 27(2), 323-350.

Texas Benefits. (n.d.). Eligibility requirements for the three programs in Texas. Retrieved from https://bit. ly/2txOKU2

Texas Education Agency. (2018). E-rate national school lunch program eligibility data year 15. Retrieved from https:// bit. $1 \mathrm{y} / 39 \mathrm{H} 8 \mathrm{oh} 7$

Texas General Land Office. (2018). Hurricane harvey: Texas at risk. Retrieved from https://bit.1y/2ZVsQGg

U.S. Census Bureau. (1998). Population of the 100 largest urban places: 1980. Retrieved from https://bit.1y/37BAKr0

U.S. Census Bureau. (2017a). American community survey, 2013-2017 American community survey 5-year estimates. Retrieved from http://factfinder. census.gov

U.S. Census Bureau. (2017b). American community survey, 2013-2017 American community survey 5-year estimates. Retrieved from http://factfinder.census.gov

U.S. Census Bureau. (2017c). American community survey, 2017 American community survey 1-year estimates. Retrieved from http://factfinder. census.gov

Wendel, H. E. W., Downs, J. A., \& Mihelcic, J. R. (2011). Assessing equitable access to urban green space: The role of engineered water infrastructure. Environmental Science \& Technology, 45(16), 6728-6734. doi:https://doi.org/10.1021/ es103949f

Zellner, M., Massey, D., Minor, E., \& Gonzalez-Meler, M. (2016). Exploring the effects of green infrastructure placement on neighborhood-level flooding via spatially explicit simulations. Computers, Environment, and Urban Systems, 59, 116-128. doi:https://doi.org/10.1016/j.compenvurbsys.2016.04.008 